\title{
Surface faulting during the August 24, 2016, Central Italy earthquake (Mw 6.0): preliminary results
}

LIVIO F. (1), MICHETTI A.M. (1), VITTORI E. (2), GREGORY L. (4), WEDMORE L. (9), PICCARDI L. (6), TONDI E. (11), ROBERTS G. (3) AND CENTRAL ITALY EARTHQUAKE WORKING GROUP

BluMEtTI A.M. (2), BONADEO L. (8), BRUNAMONTE F. (1), COMERCI V. (2), Di MANnA P. (2), Ferrario M.F. (1), FAure WALKer J. (9), Frigerio C. (1), FUMANTI F. (2); GUERRIERI L. (2), IEZZI F. (3), LEONI G. (2), McCaffrey K. (5), Mildon Z. (9), Phillips R. (4), Rhodes E. (7), WALTERS R.J. (5), WILKINSON M. (10).

(1) Università dell'Insubria - Dipartimento di Scienza ed Alta Tecnologia - Via Valleggio 11, 22100 Como (IT).

(2) ISPRA - Via Brancati, 48 - 00144 Roma (IT).

(3) Birkbeck University of London - Malet St, London (UK)

(4) University of Leeds - Leeds LS2 9JT (UK)

(5) Centre for Observation and Modelling of Earthquakes, Volcanoes and Tectonics (COMET) Durham University (UK) - Durham DH1 3LE (UK).

(6) CNR - Istituto di Geoscienze e Georisorse IGG - Via G. La Pira 450121 - Firenze (IT).

(7) Sheffield University - Western Bank, Sheffield S10 2TN, (UK).

(8) INGV - Via di Vigna Murata, 605, 00143 Roma (IT).

(9) Institute for Risk and Disaster Reduction, University College London, Gower St, London, WC1E 6BT

(10) Geospatial Research Ltd, Department of Earth Sciences, Durham University, Durham, DH1 3LE, U.K.

(11) Università di Camerino - Piazza Cavour 19f, Camerino - MC

(IT)

\begin{abstract}
We present some preliminary results on the mapping of coseismically-induced ground ruptures following the Aug. 24, 2016, Central Italy earthquake (Mw 6.0). The seismogenic source, as highlighted by InSAR
\end{abstract}


and seismological data, ruptured across two adjacent structures: the Mt. Vettore and Laga faults. We collected field data on ground breaks along the whole deformed area and two different scenarios of on-fault coseismic displacement arise from these observations. To the north, along the Mt. Vettore fault, surface faulting can be mapped quite continuously along a well-defined fault strand while such features are almost absent to the south, along the Laga fault, where flysch-like marly units are present. A major lithological control affects the surface expression of faulting, resulting in a complex deformation pattern.

\section{INTRODUCTION}

$\mathrm{O}$ August 24, 2016, an Mw 6.0 earthquake hit Central Italy between Norcia and Amatrice (Fig. 1), some tens of kilometers northwest of L'Aquila, epicentre

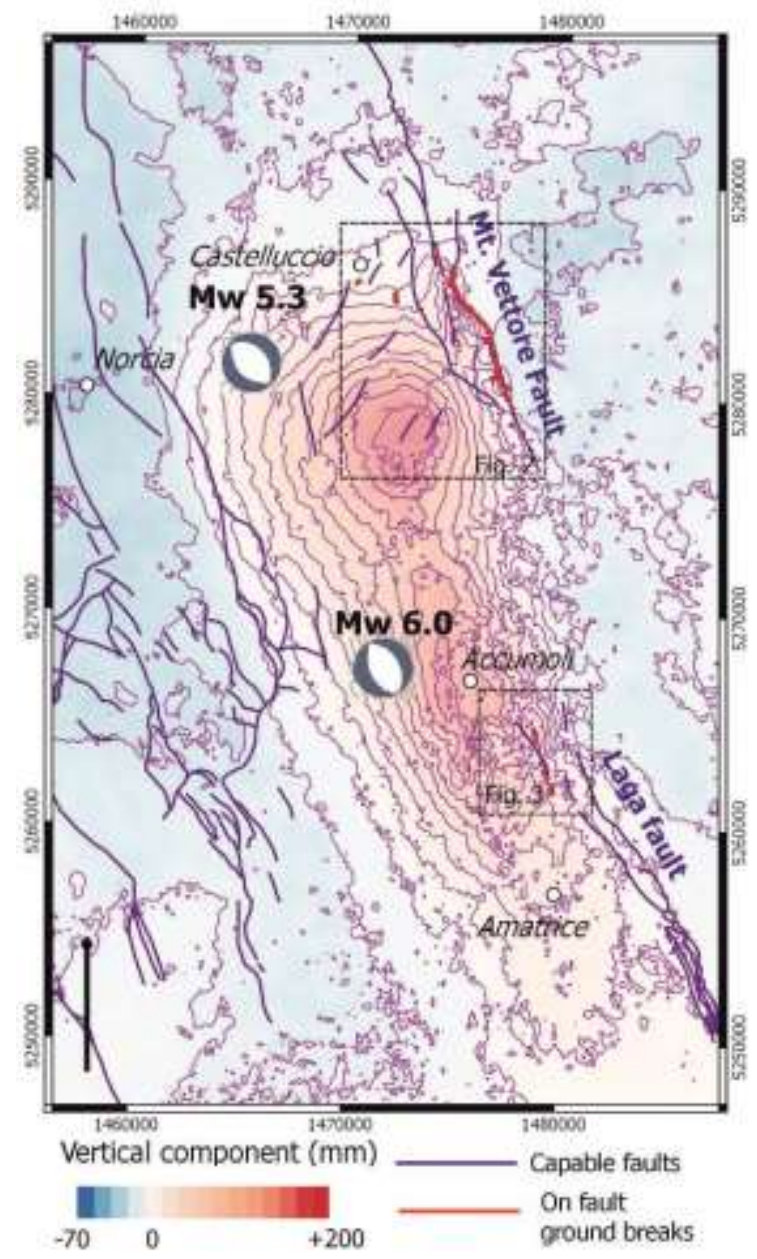

Figure 1: On-fault ground breaks, possibly linked to surface faulting, and InSAR-derived vertical coseismic surface deformation: contours every $20 \mathrm{~mm}$ (Sentinel-1; Marinkovic and Larsen, 2016). Location of main shocks and focal mechanisms (http://cnt.rm.ingv.it/tdmt) are also shown; capable faults (after ITHACA database https://goo.gl/55FwDH) are mapped for comparison. of a slightly larger earthquake in 2009 (Mw 6.3). The epicenter of the 2016 normal faulting event was located near the village of Accumoli at the border of Umbria, Marche and Latium regions. One hour later, an Mw 5.3 extensional event followed, with epicenter close to Norcia.

This region hosts several Quaternary normal faults arranged along the axis of the Apennines and capable of producing surface faulting (e.g., Blumetti et al., 1993; Calamita et al., 1994; Blumetti, 1995; Cello et al., 1997; Piccardi et al., 1997; Galadini and Galli, 2003; Roberts and Michetti, 2004; Mildon et al., 2016). For this reason, these are included in the ITHACA database, that is, the inventory of capable faults in Italy, managed by ISPRA (Fig. 1).

According to preliminary seismological, geodetic and geologic data (i.e. Gruppo di Lavoro INGV sul terremoto di Amatrice, 2016b; INGV Working group "GPS Geodesy", 2016), the seismogenic structure ruptured across a relay zone between two major NNW trending normal faults: the Mt. Vettore and Laga faults. Total rupture length is ca. 25-30 km and rupture width ca. 10-12 $\mathrm{km}$.

\section{EARTHQUAKE SURFACE FAULTING}

Initial modeling of coseismic InSAR data suggests a complicated pattern of rupture with slip across two faults separated by a right-stepping relay zone (Fig. 1). Fault geometry at depth in this critical linking section is presently poorly understood. We started surveying the day after the 
mainshock and our observations were collected quite continuously for almost 15 days, including data on after-slip on mapped ground ruptures at one location?. In the following, we describe our collected evidence of on-fault ground rupturing along the Mt. Vettore and Laga faults.

\section{The Mt. Vettore Fault}

The western slope of Mt. Vettore is the morphologic expression of a NNW-SSE trending SW dipping primary extensional tectonic element (total length $30 \mathrm{~km}$ ), cutting through carbonates of the Umbria-Sabina mesocenozoic succession (i.e., UMSTZ after Pierantoni et al., 2013) with a total stratigraphic offset of ca. $1000 \mathrm{~m}$. A major Neogene thrust (i.e., the Sibillini thrust), bordering the east side of the Apennines, displaces the units of the USMTZ over the Miocene siliciclastic turbiditic deposits outcropping within the foothills and to the SE of Mt. Vettore. Compressional structures were later dissected by Quaternary normal faults, mostly NNW-SSE trending (e.g., the Mt. Vettore fault), and this is generally interpreted as soling into the Sibillini thrust (e.g., Pizzi \&
Galadini, 2009; Pierantoni, 2013).

The south end of the fault has been coseismically reactivated in the August, 2016 earthquake. Here the slope is marked by at least two major Holocene bedrock fault scarps. The lower scarp runs at the base of the Vettore mountain front and bounds the Castelluccio basin. The upper scarp (i.e., "Cordone del Vettore"; e.g., Pierantoni et al., 2013) runs very close to the drainage divide.

We found evidence of ground ruptures on both these fault strands; nevertheless, major evidence of reactivation are reported for the upper scarp and will be described in the following.

A set of ground ruptures was mapped in the southern sector of the Vettore fault, along the the E slope of Mt. Vettoretto (Fig. 2a A-A' sector). These ruptures show normal movement (slip vector ca. N240) with a minor leftlateral component, strike ca. N150, and commonly show en-echelon right-stepping. Data on recorded displacement are reported in Figure 2a. Ground breaks run continuously, from the road SP34 (Fig. 2b) at the south end, up to the end of Mt. Vettoretto slope, where the ruptures bend slightly downslope,
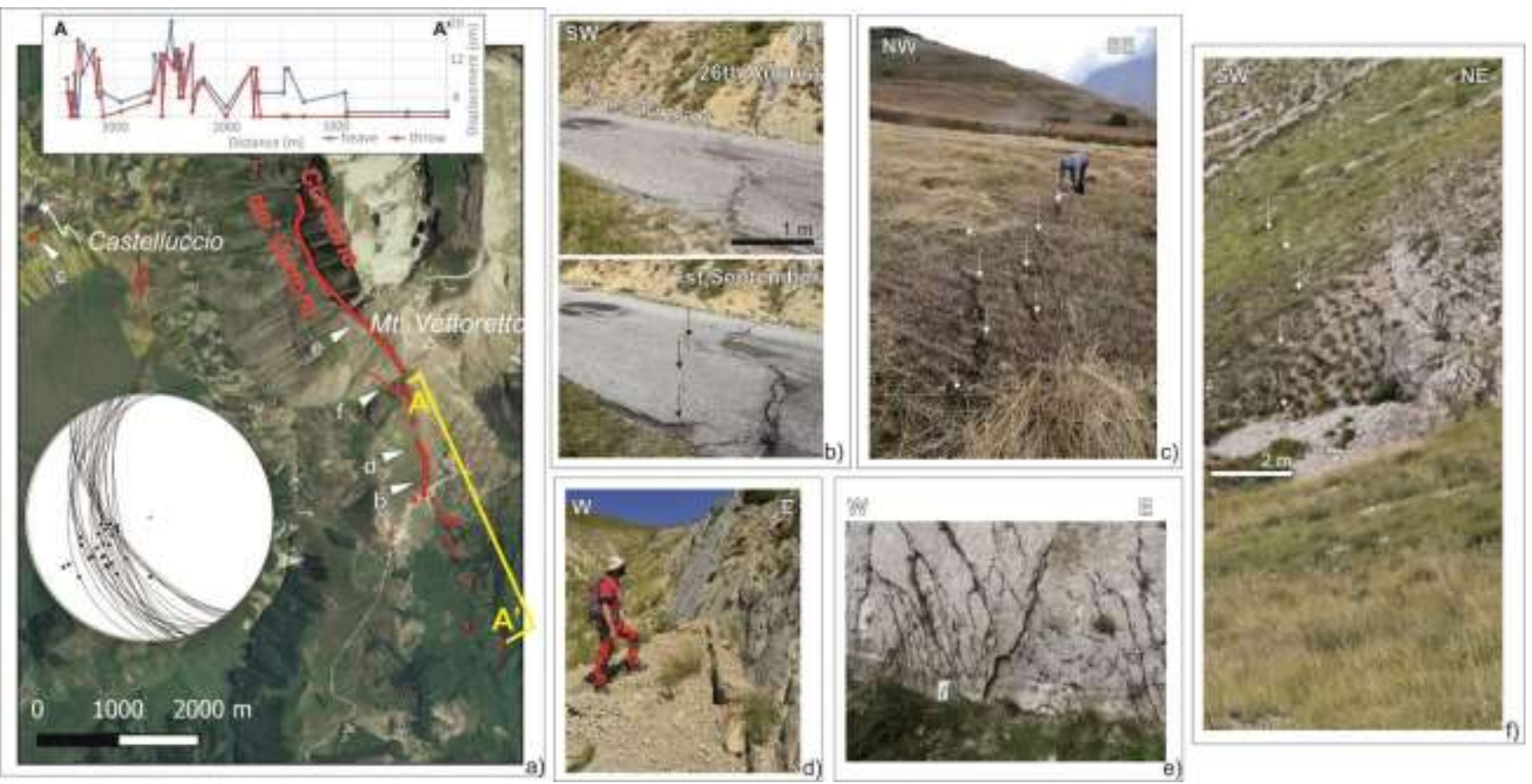

Figure 2: a) map showing of the Mt. Vettore fault area with mapped ground breaks (in red): structural data (displacement vectors and great circles for bedrock faults) and displacement profiles are also reported Google Earth base image (8/9/2010); b - f) examples of ground breaks: note the typical right-stepping enechelon pattern and the post-seismic movement documented in $b$ ). 
for a total distance of ca. $1.7 \mathrm{~km}$ (Fig. 2a, between $b$ and $f$ ). Other roughly north-south ground ruptures were found south of the road SP34, quite well aligned with the major rupture but less continuous and not clearly associated to a bedrock fault plane. They mainly trend N120-150, with individual rupture lengths generally shorter than some tens of meters and opening of some centimeters. The observed end-to-end length of this rupture zone is $1.2 \mathrm{~km}$. Vertical offsets here may exceed $20 \mathrm{~cm}$, but a gravity component may well add to the possible tectonic displacement.

In the uphill sectors, ground ruptures were found along the "Cordone del Vettore" scarp (Fig 2a, i.e., between point $f$ and the northern tip), for a length of about $2.4 \mathrm{~km}$. Here, we record an average strike of N134 and the slip vector is ca. N230. The fractures generally affect colluvium and soil, close to the bedrock fault plane (e.g., Fig. 2e) or, less frequently, at a distance of a few meters. Here, in the first days, the observed throw ranged from 2 to $25 \mathrm{~cm}$, while heave reached $10 \mathrm{~cm}$. The end-to-end length of this surface rupture zone is thus, at least, $4.5 \mathrm{~km}$.

Repeated field surveys have clearly pointed out a post-seismic evolution of the rupture, whose vertical offset is continuing to increase with time (as of $1^{\text {st }}$ September). The phenomenon is clearly evident where the fault crosses the road SP34 (Fig. 2b).

In the Castelluccio basin, a short NE-SW trending ground fracture (throw $\geq 10 \mathrm{~cm}$; length ca. $100 \mathrm{~m}$ ) runs just south of the village of Castelluccio (Fig. 2c), possibly along a secondary fault. Discontinuous cracks were also recorded, over a length of ca. $400 \mathrm{~m}$, at the foot of Mt. Vettore (Fig. 2a), along a subdued fault trace investigated by Galadini and Galli (2003).

\section{The Laga Fault}

The Laga fault, considered the source of the Oct. 7, 1639, Amatrice earthquake (DISS working group, 2015 - Io = X MCS according to the CPTI15 catalogue; Rovida et al. 2016), is a normal structure running at the base of the Mt. Gorzano range and displacing flysch and marly units (i.e. infilling of the Miocene Laga basin; e.g., Pierantoni et al., 2013) for a stratigraphic offset of ca. $1500 \mathrm{~m}$ (Boncio et al., 2004).

Our survey along the N part of the fault, between Accumoli and Amatrice, has not detected unambiguous evidence of surface faulting to date. Nevertheless, some effects may be in some way related to the coseismic slip on the fault, as suggested by InSARderived surface deformation. 

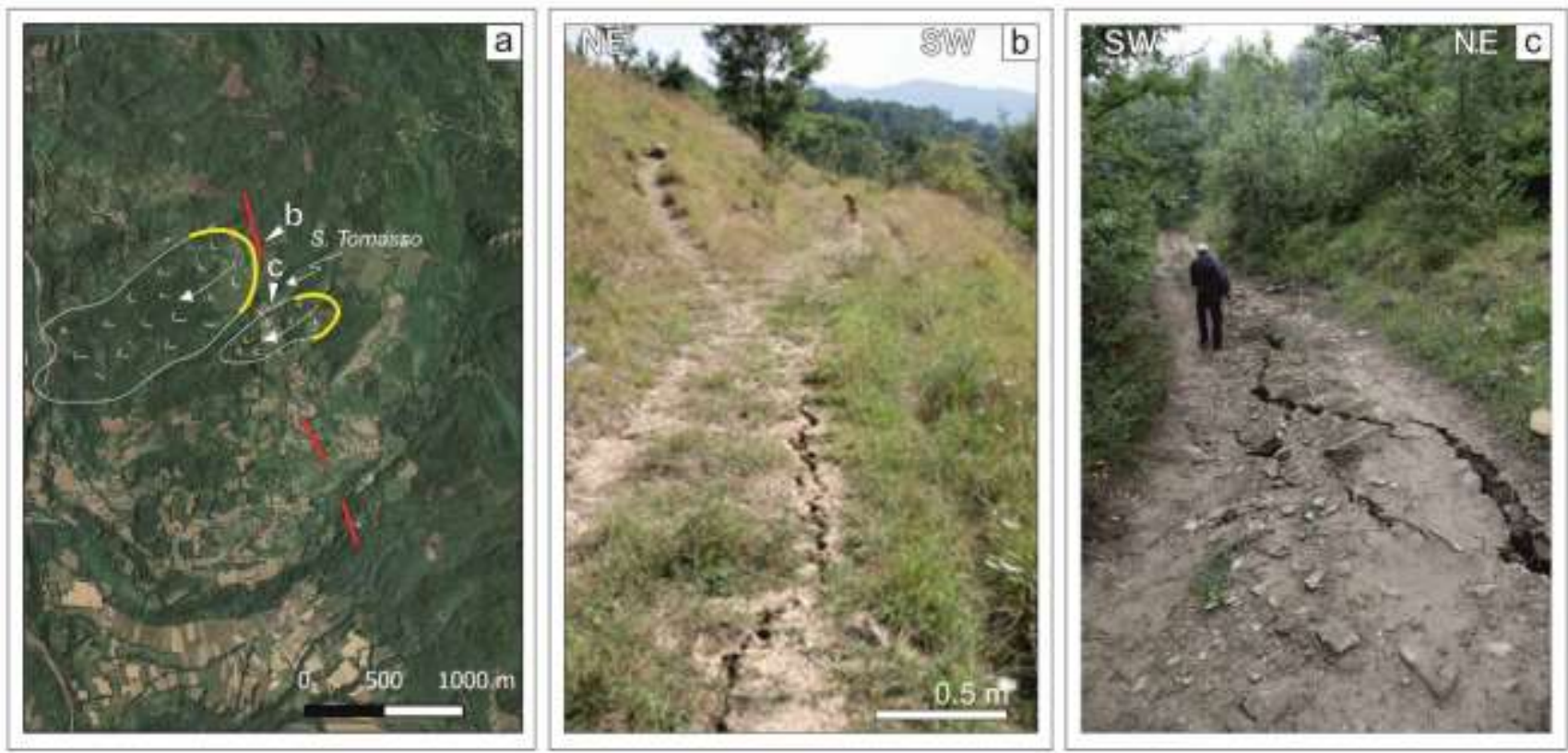

Figure 3: a) map of the Laga fault area: ground breaks are mapped in red; two known landslides are indicated (landslide crown in yellow -IFFI database; https:/ /goo.gl/bE7uTN ); b) and c) location are indicated

For instance, in the lower part of the slope between San Tommaso village and the valley floor, several ground breaks were observed (Fig. 3). These fractures follow the slope orientation and consist of 20 to $25 \mathrm{~m}$ long surface breaks, 5 to $20 \mathrm{~cm}$ wide, N140 - N160 trending and west-dipping. The observed ground breaks are located near the head of a large landslide, suggesting that they may be tension cracks connected to the semicrescentic crown of a seismically-triggered slide. The surface ruptures affect the colluvial deposits covering the area andwe did not observe, if any, evidence of ruptured bedrock. Nevertheless, the affected area corresponds to the zone where, according to InSAR data, significant deformation occurred (i.e., max. $15-18 \mathrm{~cm}$ of LOS vertical component near this area, see Figure 1).

We suppose that the reason why little or no ground rupture occurred is that the local clayey and arenaceous lithology in the Amatrice area is less prone to reveal the expected modest surface faulting phenomena when compared to the limestone and hard compacted slope debris of Mt. Vettore.

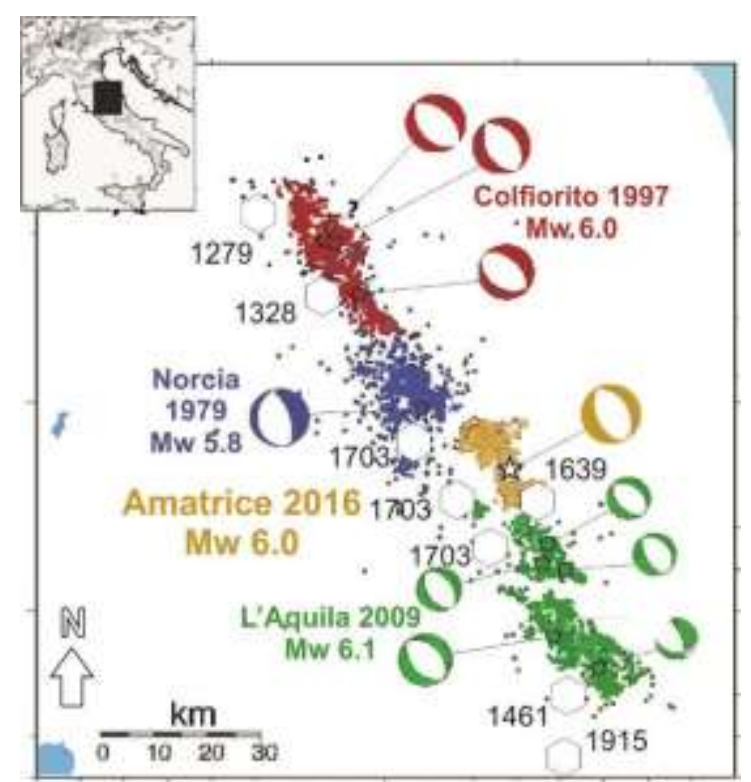

Figure 4: Most recent and significant seismic sequence that hit Central Apennines during the last decades (modified after: Gruppo di Lavoro INGV sul Terremoto di Amatrice, 2016a). 


\section{FINAL REMARKS}

The assessed primary surface faulting along the Mt. Vettore Fault is relevant to earthquake geology and paleoseismology, and therefore to seismic hazard assessment based on geological investigation. This earthquake is consistent with the observation that the threshold for surface faulting during extensional events in the Apennines is between Mw 5.5 and 6.0 (e.g., Serva et al., 2002). However, it would be difficult to recognize such small slip events in paleoseismological trenches. For example, the paleoseismic site excavated by Galadini and Galli (2003) across a fault on the hangingwall of the Mt. Vettore fault revealed surface faulting events probably associated, according to the authors, with larger earthquakes (possibly $\mathrm{Mw}$ $\approx 6.5-7.0$ ).

Given the series of events with roughly decadal inter-event times that have hit the region between Gubbio and the high Sangro valley since 1984 along the Apennine fault system, the 2016 Central Italy earthquake in some ways partially? fills the "gap" between the 1997 Colfiorito and the 2009 L'Aquila earthquakes. A similar "gap" may exist for the area southeast of L'Aquila, between the 1984 and the 2009 earthquakes (e.g., Tondi and Cello, 2003). Seismic gaps

(sensu lato) and redistribution of Coulomb stress from recent earthquakes need to be studied in more detail because they may suggest an increased probability of occurrence of an $M \geq 6$ event on the Laga Fault between Amatrice and Campotosto.

The overall scenario emerging from this earthquake, from macroseismic observations and earthquake-induced environmental effects (Guerrieri et al., this volume) is com- plex. Given that the seismogenic source ruptured in a relay zone between two major fault segments, with contrasting topography, lithology and buoldings vulnerability we have two different outcomes along these two segments:

a) To the north, along the Mt. Vettore fault, evident primary and distributed surface faulting, tipically as re-activation of preexisting free-face scarps in limestone. Little damage was recorded, due to the sparsely inhabited area (i.e., Castelluccio plain) and to retrofitting of the buildings, performed following the Sept. 19, 1979 Norcia event (Mw 5.9);

b) To the south, little or no ground rupture, due to an evident lithological control, but extensive damage to villages with near-field site effects.

The ongoing studies will hopefully shed light on this matter of great relevance for reliable seismic hazard assessment.

\section{REFERENCES}

Blumetti, A. M., Dramis, F. and Michetti, A.M. (1993). Fault generated mountain fronts in the Central Apennines (Central Italy): geomorphological features and seismotectonic implications. Earth Surface Processes and Landforms, 18, 203-223.

Blumetti, A. M. (1995). Neotectonic investigations and evidence of paleoseismicity in the epicentral area of the January-February 1703, Central Italy, earthquakes. Perspectives in paleoseismology, 6, 83-100.

Boncio, P., Lavecchia, G., Milana, G., and Rozzi, B. (2004). Seismogenesis in Central Apennines, Italy: an integrated analysis of minor earthquake sequences and structural 
data in the Amatrice-Campotosto area. Annals of Geophysics.

Calamita, F., Coltorti, M., Farabollini, P., and Pizzi, A. (1994). Le faglie normali quaternarie nel-la dorsale appenninica umbromarchigiana: proposta di un modello di tettonica di inversione. Studi Geologici Camerti, 211-225.

Cello, G., Mazzoli, S., Tondi, E. and Turco, E. (1997). Active tectonics in the central Apennines and possible implications for seismic hazard analysis in peninsular Italy. Tectono-physics 272, 43-68.

Coltorti, M. and Farabollini, P. (1995). Quaternary evolution of the Castelluccio di Norcia basin (Umbro-Marchean Apennines, central Italy), Il Quaternario 8, 149166.

DISS Working Group (2015). Database of Individual Seismogenic Sources (DISS), Version 3.2.0: A compilation of potential sources for earthquakes larger than M 5.5 in Italy and surrounding areas. http://diss.rm.ingv.it/diss/, Istituto Nazionale di Geofisica e Vulcanologia; DOI:10.6092/INGV.IT-DISS3.2.0

Faure Walker, J., Roberts, G. P., Cowie, P. A., Papanikolaou, I., Michetti, A. M., Sammonds, P., ... \& Phillips, R. J. (2012). Relationship be-tween topography, rates of extension and mantle dynamics in the actively-extending Italian Apennines. Earth and Planetary Science Letters, 325, 76-84.

Galadini, F. and Galli, P. (2003). Paleoseismology of silent faults in the Central Apennines (Italy): the Mt. Vettore and Laga Mts. faults. Annals of Geophysics.

Gruppo di Lavoro INGV sul Terremoto di Amatrice, . (2016a). Primo rapporto di sintesi sul terremoto di Amatrice Ml 6.0 del 24
Agosto 2016 (Italia centrale). Zenodo. DOI: 10.5281 / zenodo.61121

Gruppo di Lavoro INGV sul terremoto di Amatrice. (2016b). Secondo rapporto di sintesi sul terremoto di Amatrice Ml 6.0 del 24 Agosto 2016 (Italia centrale). Zenodo. DOI: 10.5281/zenodo. 154400

INGV Working group "GPS Geodesy (GPS data and data analysis center)", . (2016). Preliminary co-seismic displacements for the August 24, $2016 \mathrm{Ml}$ 6, Amatrice (central Italy) earthquake from the analysis of continuous GPS stations. Zenodo. DOI 10.5281/zenodo.61355

Marinkovic P. and Larsen Y. (2016). Mapping and analysis of the Central Italy Earthquake (2016) with Sentinel-1 A/B interferometry. Zenodo, DOI 10.5281/zenodo.61133

Mildon, Z. K., Roberts, G. P., Walker, J. P. F., Wedmore, L. N. and McCaffrey, K. J. (2016). Active normal faulting during the 1997 seismic sequence in Colfiorito, Umbria: Did slip propagate to the surface?. Journal of Structural Geology, 91, 102-113.

Piccardi, L., Sani, F., Bonini, M., Boccaletti, M., Moratti, G. and Gualtierotti, A. (1997). Deformazioni quaternarie nell'Appennino Centro-Settentrionale: evidenze ed implicazioni. Il Quaternario, 10 (2), 273-280.

Pierantoni, P., Deiana, G., and Galdenzi, S. (2013). Stratigraphic and structural features of the Sibillini Mountains (Umbria-Marche Apennines, Italy). Italian Journal of Geosciences, 132(3), 497-520.

Pizzi, A. and Galadini, F. (2009). Pre-existing cross-structures and active fault segmentation in the northern-central Apennines (Italy). Tectonophysics, 476(1), 304-319.

Roberts, G. P. and Michetti, A.M. (2004). Spatial and temporal variations in growth rates 
along active normal fault systems: an example from The Lazio-Abruzzo Apennines, central Italy. Journal of Structural Geology, 26(2), 339-376.

Rovida A., Locati M., Camassi R., Lolli B., Gasperini P. (eds) (2016). CPTI15, the 2015 version of the Parametric Catalogue of Italian Earthquakes. Istituto Nazionale di Geofisica e Vulcanologia. doi:http://doi.org/10.6092/INGV.ITCPTI15

Serva, L., Blumetti, A. M., Guerrieri, L., Michetti, A. M. (2002). The Apennine intermountain basins: the result of repeated strong earthquakes over a geological time interval. Bollettino della Società geologica italiana, 121(1), 939-946.

Tondi, E. and Cello, G. (2003). Spatiotemporal evolution of the Central Apennines fault system (Italy). Journal of Geodynamics, 36(1), 113-128. 